\title{
A checklist of chiggers from Brazil, including new records (Acari: Trombidiformes: Trombiculidae and Leeuwenhoekiidae)
}

\author{
Fernando de Castro Jacinavicius ${ }^{1,2}$, Ricardo Bassini-Silva ${ }^{2}$, \\ Jairo Alfonso Mendoza-Roldan², Almir Rogério Pepato ${ }^{3}$, \\ Ronald Ochoa ${ }^{4}$, Cal Welbourn ${ }^{5}$, Darci Moraes Barros-Battesti ${ }^{6}$
}

I Laboratório Especial de Coleçóes Zoológicas, Instituto Butantan, São Paulo, SP; Brazil 2 Departamento de Medicina Veterinária Preventiva e Saúde Animal, FMVZ-USP, São Paulo, SP, Brazil 3 Departamento de Zoologia, Instituto de Ciências Biológicas, Universidade Federal de Minas Gerais, Belo Horizonte, MG, Brazil 4 Systematic Entomology Laboratory, United States Department of Agriculture, Agricultural Research Service, Beltsville, MD, USA 5 Florida State Collection of Arthropods, Division of Plant Industry, Florida Department of Agriculture and Consumer Services, Gainesville, FL, USA 6 Departamento de Patologia Veterinária, Faculdade de Ciências Agrárias e Veterinárias-UNESP, Jaboticabal, SP, Brazil

Corresponding author: Darci Moraes Barros-Battesti (dbattesti@yahoo.com.br)

Academic editor: V. Pesic | Received 30 November 2017 | Accepted 16 January 2018 | Published 14 March 2018

http://zoobank.org/91FC9D7B-9A2E-49C2-979B-OFA161AB6CEO

Citation: Jacinavicius FC, Bassini-Silva R, Mendoza-Roldan JA, Pepato AR, Ochoa R, Welbourn C, Barros-Battesti DM (2018) A checklist of chiggers from Brazil, including new records (Acari: Trombidiformes: Trombiculidae and Leeuwenhoekiidae). ZooKeys 743: 1-41. https://doi.org/10.3897/zookeys.743.22675

\begin{abstract}
A checklist of the family Trombiculidae and Leeuwenhoekiidae is presented, containing 63 species in 30 genera of chiggers from 80 different hosts and 146 localities in Brazil. The type locality and depository are provided, including new locality and host records for the country.
\end{abstract}

\section{Keywords}

Brazil, Chigger mites, Cricetidae, Didelphidae, distribution 


\section{Introduction}

The mites known as "chiggers" or "chigger mites" belong to three families: Trombiculidae Ewing, 1944, Leeuwenhoekiidae Womersley, 1944, and Walchiidae Ewing, 1946 sensu Wen (1999). The larvae are ectoparasites of vertebrates, and during the parasitism, they liquefy and suck the host's epithelial tissue by the enzymatic action of their saliva. Blood is not ingested in this process, but some blood cells can be found in the gut of the mite (Jones 1950). Deutonymphs and adults are free living predators (Crossley 1960).

Studies of the biology and taxonomy of these mites were intensified during World War II, thus increasing considerably the number of known species. Soldiers were attacked in encampments and contracted rickettsioses from infected larvae (Wharton and Fuller 1952). According to these authors, in the front of the situation, the public health departments were faced with the need for cataloging studies, description, morphology, and biology of these mites. Although they are considered potential vectors of pathogens, the role of these mites in the epidemiology of rickettsiosis is unknown in the Neotropical region (Azad and Beard 1998, Poinar and Poinar 1998).

In South America, the countries that have a checklist of chiggers species are: Venezuela (Brennan and Reed 1975), Peru (Brennan and Jones 1961), Surinam (Brennan and Lukoschus 1971) and recently Chile (Stekolnikov and González-Acuña 2015). Ewing (1931) compiled the first list of chigger mites from the New World, eight species from Brazil. Wharton and Fuller (1952) increased the number by eight genera and 18 species. Fonseca (1955) reported the first human hosts for Brazil. Brennan and Goff (1977) reported 87 chigger genera for the Nearctic and Neotropical regions, of which 18 were recorded from Brazil.

The Brazilian territory is composed by five regions (north, northeast, centralwest, southeast and south), 26 states and one federal district (Contel 2014). Between the 1970s and 1990s, new species were described by various researchers from specimens collected primarily in the northern and central-western parts of the country, but have never been summarized (Stekolnikov and González-Acuña 2015). Therefore, here we are compiling a checklist of species from Brazil, including new hosts and localities.

\section{Materials and methods}

In the checklist, the taxa comprise two families, Trombiculidae and Leeuwenhoekiidae. The genera and species are arranged alphabetically, in the follow format: Genus - Valid name, author and data; Species - Checklist number, valid name of species, author, date, type locality, host, and type depository, in parenthesis are the typification and the collection number, when available. In cases where the original host name has changed, the current host name is listed with the original host name in parenthesis. The host species were updated based on the IUCN (2017). 
The following abbreviations were used:

BPBM USA, Hawaii, Honolulu, Bernice Pauahi Bishop Museum;

FMNH USA, Illinois, Chicago, Field Museum of Natural History Chicago (cited in original description as CNHM);

IBSP Brazil, São Paulo, São Paulo, Instituto Butantan;

MNRJ Brazil, Rio de Janeiro, São Cristovão, Universidade do Rio Janeiro, Museu Nacional;

MZSP Brazil, São Paulo, São Paulo, Museu de Zoologia da Universidade de São Paulo;

NHMUK United Kingdom, London, The Natural History Museum [formerly British Museum (Natural History)] (cited in original description as BMNH or BM);

OMNH USA, Oklahoma, Norman, University of Oklahoma, Oklahoma Museum of Natural History;

OSAL USA, Ohio, Columbus, Ohio State University Acarology Laboratory;

RMNH Netherlands, Leiden, Naturalis Biodiversity Centre [formerly Rijksmuseum van Natuurlijke Historie];

SAM Australia, South Australia, Adelaide, South Australian Museum;

USNM USA, Washington D.C., National Museum of Natural History, [formerly United States National Museum] which is housed at the Systematic Entomology Laboratory (BARC-USDA-ARS), cited in original descriptions as NMNH.

Details of the records in Brazil were provided based on the bibliographic review, followed to the new records for the country, when available. The new records from the checklist are based on the material deposited in the IBSP collection. Some of these species were also reported outside Brazilian territory. These recordings of literature were included in other records.

In addition, a list of chiggers from Brazil is summarized with their respective hosts (Appendix 1) and a list of vertebrate hosts and their respective chiggers and the published information from Brazil (Appendix 2).

\section{Results}

A Brazilian checklist with eight species of the family Leeuwenhoekiidae and 55 of the family Trombiculidae, totaling 63 chigger species in 30 genera from approximately 70 different hosts is presented. Some regions just have one or two chigger records and most of these records are represented by the type series. Species of the family Walchiidade were never recorded in the Brazilian territory until this work.

The chigger species P. aemulata, Q. flochi, Q. mirandae, and Q. trapezoides are reported for the first time in Brazil, and new records of locality for T. bakeri and new localities and hosts for the species C. spinosus, E. tinami, K. brasiliensis, Q. pazca, and S. tamarina are provided too. 


\section{Checklist of larvae chigger species (in alphabetical order) recorded from Brazil}

\section{Family LEEUWENHOEKIIDAE Womersley, 1944}

\section{Genus Apolonia Torres \& Braga, 1938: 172}

1. Apolonia tigipioensis Torres \& Braga, 1938: 172; Tigipió, Pernambuco state, Brazil, ex Gallus gallus domesticus; IBSP (syntype, $\mathrm{n}^{\circ}$ 1954).

Records from Brazil. In addition to the type data, Carneiro $(1949,1952)$ reported A. tigipioensis parasitizing humans and Nothura maculosa cearensis (Tinamiformes) in Limoeiro (Pernambuco). This chigger was also found parasitizing the birds Struthio camelus (Struthioniformes) and Passer domesticus (Passeriformes) in Petrolina (Pernambuco) (Ornelas-Almeida et al. 2007).

Other records. Venezuela (Brennan and Reed 1975).

Genus Hannemania Oudemans, 1911: 137

2. Hannemania hepatica Fonseca, 1936: 30; Butantan, São Paulo, São Paulo state, Brazil; ex. Leptodactylus latrans (= L. ocellatus); IBSP (holotype, $\mathrm{n}^{\circ} 31$ ).

Records from Brazil. Only the type data.

3. Hannemania hylodeus (Oudemans, 1910): 88; Brazil, ex Hylodes sp.; RMNH ( ${ }^{\circ}$ 6247).

Records from Brazil. Only the type data, no locality information was provided by the author.

4. Hannemania newsteadi Sambon, 1928: 127; Urucum, Mato Grosso do Sul state, Brazil, ex Hyla rubra; NHMUK.

Records from Brazil. Only the type data.

5. Hannemania stephensi Sambon, 1928: 127; Tombador, Mato Grosso state, Brazil, ex Pristimantis conspicillatus (= Hylodes conspicillatus); NHMUK.

Records from Brazil. Only the type data.

Genus Leeuwenhoekia Oudemans, 1911: 137

6. Leeuwenhoekia verduni (Oudemans, 1910): 88; southern Brazil; ex. Didelphis sp., “opossum" RMNH (n 6250).

Records from Brazil. Only the type data, this species was described from an unknown location in southern Brazil. 


\section{Genus Whartonia Ewing, 1944: 102}

7. Whartonia nudosetosa (Wharton, 1938): 142; Cave near Oxkutzcab, Yucatan, Mexico, ex Artibeus jamaicensis yucatanicus and "Peteropteryx canina canina"; USNM $\left(\mathrm{n}^{\circ} 1264\right)$.

Note. The correct host name is Peropteryx macrotis, originally described as Verpertillio caninus.

Records from Brazil. Silveira et al. (2015) reported this species from Medina and Sáo José da Safira (Minas Gerais state) on Carollia perspicillata (Chiroptera).

Other records. Costa Rica (Webb and Loomis 1977); Guatemala (Brennan and Dalmat 1960); Jamaica (Brennan 1953); Nicaragua (Webb and Loomis 1977); Mexico (Wharton 1938, Hoffmann 1949, Loomis 1969, Webb and Loomis 1977); Surinam (Brennan and van Bronswijk 1975); Trinidad (Brennan and Jones 1960, Brennan 1967) and Venezuela (Reed and Brennan 1975).

8. Whartonia pachywhartoni Vercammen-Grandjean, 1966: 282; Lagoa Santa, Minas Gerais state, Brazil, ex Micronycteris megalotis, USNM (holotype, $\mathrm{n}^{\circ}$ 10462/6).

Records from Brazil. In addition to the type data, W. pachywhartoni was found in São José da Safira (Minas Gerais) parasitizing the bat C. perspicillata (Silveira et al. 2015).

\section{Family TROMBICULIDAE Ewing, 1944}

Genus Aitkenius Brennan, 1970: 1694

9. Aitkenius vellosus Brennan, 1970: 1695; Belém, Pará state, Brazil, ex Proechimys guyannensis, USNM (holotype and paratypes, $\mathrm{n}^{\circ}$ 48876), FMNH (paratypes) and NHMUK (paratypes).

Records from Brazil. In addition to the type data, A. vellosus was also found at the same locality, on Hylaeamys megacephalus (Rodentia), and in Bragança (Pará) on the water rat Nectomys squamipes (Rodentia) (Brennan 1970d).

\section{Genus Arisocerus Brennan, 1970: 32}

10. Arisocerus amapensis Brennan, 1970: 32; Serra do Navio, Amapá state, Brazil, ex Euryoryzomys macconnelli; USNM (holotype and paratypes, $\mathrm{n}^{\circ}$ 49368).

Records from Brazil. In addition to the type data, this species was also found at the same locality, on H. megacephalus, and in Belém (Pará) parasitizing H. megacephalus and P. guyannesis (Brennan 1970c).

Other records. Suriname (Brennan 1970c, Brennan and van Bronswijk 1975) and Venezuela (Brennan and Reed 1975). 
11. Arisocerus hertigi (Brennan \& Jones, 1964): 308; Sommerfield, Paraguay, ex "agouti"; USNM (holotype and paratypes, n 43427), FMNH (paratypes), OSAL (paratypes), BPBM (paratypes).

Records from Brazil. This species was found in Brasília (Federal District), parasitizing the marsupial Didelphis albiventris (Didelphimorphia) (Goff and Gettinger 1989). In addition, $A$. hertigi was found on the Archipelago Moleques do Sul (Santa Catarina) parasitizing Cavia intermedia (Rodentia) (Regolin et al. 2015).

Other records. Paraguay (Brennan and Jones 1964a).

\section{Genus Blankaartia Oudemans, 1911: 123}

12. Blankaartia shatrovi Bassini-Silva \& Barros-Battesti, 2016: 83; São Paulo, São Paulo state, Brazil, ex "bird"; IBSP (holotype and paratypes, $n^{\circ} 367$ ).

Records from Brazil. In addition to the type data, this species was also found in Coronel Pacheco (Minas Gerais) parasitizing Trichothraupis melanops (Passeriformes) (Bassini-Silva et al. 2016).

13. Blankaartia sinnamaryi Floch \& Fauran, 1956: 3; Sinnamary, French Guiana, ex Homo sapiens.

Records from Brazil. This species was found in Paraty (Rio de Janeiro) parasitizing Manacus manacus (Passeriformes), in Juiz de Fora (Minas Gerais) parasitizing Picumnus cirratus (Piciformes), Tachyphonus coronatus, Thamnophilus caerulescens and Turdus rufiventris (Passeriformes), and in Coronel Pacheco (Minas Gerais) parasitizing Conopophaga lineata and Turdus albicollis (Passeriformes) (Bassini-Silva et al. 2016).

Other records. Costa Rica (Arnold 1970, Stekolnikov et al. 2007), Cuba (Daniel and Stekolnikov 2003), French Guiana (Floch and Fauran 1956), Jamaica (Brennan 1953), Panama (Brennan and Yunker 1966), Peru (Brennan and Jones 1961a), Surinam (Brennan and van Bronswijk 1975), Trinidad (Brennan and Jones 1960), USA (Brennan 1965, Spalding et al. 1997) and Venezuela (Brennan and Reed 1975).

\section{Genus Buclypeus Brennan, 1972: 1178}

14. Buclypeus catatonus Brennan, 1972: 1178; Belém, Pará state, Brazil, ex Proechimys guyannensis; USNM (holotype and paratypes, $\mathrm{n}^{\circ}$ 49322), NHMUK (paratypes), BPBM (paratypes) and FMNH (paratypes).

Records from Brazil. Only the type data.

15. Buclypeus ignotus (Brennan, 1971): 214; Belém, Pará state, Brazil, ex Proechimys guyannensis, USNM (holotype and paratypes, $\mathrm{n}^{\circ}$ 49322), NHMUK (paratypes) and FMNH (paratypes).

Records from Brazil. Only the type data. 
Genus Caamembecaia Gazêta, Amorim, Bossi, Linhares \& Serra-Freire, 2006: 137

16. Caamembecaia gratiosus Gazêta, Amorim, Bossi, Linhares \& Serra-Freire, 2006: 137; Itatiaia National Park, Rio de Janeiro state, Brazil, ex Trinomys gratiosus; MNRJ (holotype, $\mathrm{n}^{\circ}$ 67498).

Records from Brazil. Only the type data.

Genus Chiroptella Vercammen-Grandjean, 1960: 469

17. Chiroptella (Oudemansidium) australis (Brennan, 1970): 810; Pedras Negras, Rondônia state, Brazil, ex Nyctinomops laticaudatus (= Tadarida laticaudata); USNM (holotype and paratypes, $\mathrm{n}^{\circ}$ 50192), NHMUK (paratypes) and FMNH (paratypes).

Records from Brazil. Only the type data.

Other records. Venezuela (Brennan and Reed 1975).

Genus Colicus Brennan, 1970: 271

18. Colicus brasiliensis Goff, Whitaker \& Dietz, 1983: 185; São Roque de Minas, Minas Gerais state, Brazil, ex Oligoryzomys formesi (= Oryzomys fornesi) and Cerradomys subflavus (= Oryzomys subflavus); BPBM (holotype, $\mathrm{n}^{\circ} 12711$ and paratypes).

Records from Brazil. Only the type data.

19. Colicus icomi Brennan, 1970: 271; Serra do Navio, Amapá state Brazil, ex Proechimys guyannensis; USNM (holotype and paratypes, $\mathrm{n}^{\circ}$ 49342).

Records from Brazil. Only the type data.

Other records. Surinam (Brennan and van Bronswijk 1975).

20. Colicus spinosus Goff \& Gettinger, 1989: 554; Brasília, Federal District, Brazil, ex Gracilinannus agilis; MZSP (holotype), BPBM (paratypes), OMNH (paratypes) and USNM (paratypes).

Records from Brazil. Only the type data.

New record. IBSP 11116 (1 larva), Condomínio Vila Verde, Itapevi, São Paulo, state of São Paulo, 29-XI-2012, Monodelphis sp. (Didelphimorphia) (\#VV 105).

Genus Euschoengastia Ewing 1938: 293

21. Euschoengastia trouessarti (Oudemans, 1910): 87; southern Brazil; ex Didelphis sp.; RMNH.

Records from Brazil. Only the type data, this species was described from an unknown location in southern Brazil. 


\section{Genus Eutrombicula Ewing, 1938: 293}

22. Eutrombicula alfreddugesi Oudemans, 1910: 84; México, ex Homo sapiens; RMNH.

Records from Brazil. This species was found in Correntes (Mato Grosso) parasitizing the snake, Xenodon merremii and a human in São Paulo (São Paulo) (Fonseca 1932a). This species was also found in Unaí (Minas Gerais) and Pirenópolis (Goiás) parasitizing Tropidurus oreadicus, Tropidurus itambere and Tropidurus torquatus (Squamata) (Carvalho et al. 2006). There are additional records from Chapada do Araripe (Ceará) on Tropidurus hispidus (Squamata) (Delfino et al. 2011) and from Morro do Chapéu (Bahia), on Tropidurus hispidus, Tropidurus cocorobensis, Tropidurus semitaeniatus and Tropidurus erythrocephalus (Menezes et al. 2011). Recently this species was found parasitizing goats in Maranhão state (Faccini et al. 2017).

Other records. Bolivia (Brennan 1970a); Costa Rica (Arnold 1970); Cuba (Daniel and Stekolnikov 2004); USA (Rohani and Cromroy 1979); Guatemala (Brennan and Dalmat 1960); Mexico (Oudemans 1910, Wharton 1938, Pearse et al. 1936, Hoffmann 1949, Jenkins 1949, Kroman et al. 1967, Loomis 1969, Loomis and Spath 1969, Hoffmann 1990, Estébanes-González and Cervantes 2005); Panama (Brennan and Yunker 1966); Surinam (Brennan and van Bronswijk 1975; Brennan and Lukoschus 1971); Trinidad (Brennan and Jones 1960) and Venezuela (Brennan and Reed 1974).

23. Eutrombicula batatas (Linnaeus, 1758): 617; Surinam, ex unknown host; NHMUK.

Records from Brazil. This species was found in Manaus and Carvoeiro (Amazonas) parasitizing $G$. domesticus, and in Belém (Pará), parasitizing Meleagris gallopavo (Galliformes) (Ewing 1925). There are also records of E. batatas parasitizing Dasyprocta agouti (Rodentia) and unidentified Cervidae in Pará state (Bequaert 1926). Confalonieri and De Carvalho (1973) found E. batatas parasitizing G. domesticus in Mangaratiba (Rio de Janeiro). This species was also found parasitizing equines in Cáceres (Mato Grosso) (Confalonieri and Benez 1976) and on goats in Maranhão state (Faccini et al. 2017).

Other records. Argentina (Brennan and Jones 1964b); Bolivia (Brennan 1970a); Costa Rica (Arnold 1970); Curaçao (Brennan 1967); Guatemala (Brennan and Dalmat 1960); Jamaica (Brennan 1953); Mexico (Linnaeus 1758, Jenkins 1949, Loomis and Stephens 1962, Loomis 1969, Hoffmann 1990, Estébanes-González and Cervantes 2005); Panama (Brennan and Yunker 1966); Surinam (Linnaeus 1758, Brennan and Lukoschus 1971, Brennan and van Bronswijk 1975); Trinidad (Brennan and Jones 1960, Bennett and Loomis 1980) and Venezuela (Brennan and Reed 1974).

24. Eutrombicula bruyanti (Oudemans, 1910): 85; southern Brazil; ex Didelphis sp. "opossum"; RMNH.

Records from Brazil. Only the type data, this species was described from an unknown location in southern Brazil. 
25. Eutrombicula goeldii (Oudemans, 1910): 84; Brazil; ex Dasyprocta aguti; RMNH.

Records from Brazil. Only the type data, no locality information was provided by the author.

Other records. Bolivia (Brennan 1970a); Colombia (Boshell and Kerr 1942, Brennan 1968a); Costa Rica (Arnold 1970); Dominica (Brennan 1967); Panama (Brennan and Yunker 1966); Surinam (Brennan 1970c, Brennan and Lukoschus 1971, Brennan and van Bronswijk 1975); Trinidad (Brennan and Jones 1960); Venezuela (Brennan and Reed 1974).

26. Eutrombicula tinami (Oudemans, 1910): 84; Brazil; ex Crypturus noctivagus; RMNH. Records from Brazil. Only the type data, no locality information was provided by the author.

New record. IBSP 11368 (8 larvae), Condomínio Vila Verde, Itapevi, São Paulo, state of São Paulo, 19-VI-2013, Didelphis aurita (\#VV 107).

Other records. Panama (Brennan and Lukoschus 1971); Surinam (Brennan and Lukoschus 1971); and Venezuela (Brennan and Reed 1974).

\section{Genus Fonsecia Radford, 1942: 56}

27. Fonsecia ewingi (Fonseca, 1932): 153; Correntes, Mato Grosso state, Brazil, ex Xenodon merremii; IBSP (syntypes, $\mathrm{n}^{\circ} 27$ ).

Records from Brazil. In addition to the type data, this species was also found at the following localities: Quiteriozinho (Mato Grosso), Birigui, Guatapará, Jacaré, Matão, Penápolis, Promissão and Silvania (São Paulo), Morrinhos (Goiás) and Rio Negro (Paraná) (Fonseca 1932b).

Other records. Trinidad (Brennan 1967).

28. Fonsecia ophidica (Fonseca, 1932): 151; Promissão, São Paulo state, Brazil, ex Xenodon merremii; IBSP (syntypes, $\mathrm{n}^{\circ} 29$ ).

Records from Brazil. In addition to the type data, this species was also found in Matão (São Paulo), on the same host (Fonseca 1932b).

29. Fonsecia travassosi (Fonseca, 1936): 29; Angra dos Reis, Rio de Janeiro state, Brazil; ex Spilotes pullatus; IBSP (holotype, $\mathrm{n}^{\circ} 30$ ).

Records from Brazil. Only the type data.

\section{Genus Hooperella Vercammen-Grandjean, 1967: 853}

30. Hooperella spinirostra (Vercammen-Grandjean, 1967): 854; Lagoa Santa, Minas Gerais state, Brazil, ex Micronycteris megalotis; USNM (holotype, nº 10462/B).

Records from Brazil. Only the type data. 
Genus Kymocta Yunker \& Brennan, 1962: 572

31. Kymocta brasiliensis (Fonseca, 1936): 32; Butantan, São Paulo, São Paulo state, Brazil, ex "wild mouse"; IBSP (holotype, $\mathrm{n}^{\circ} 334$ ).

Records from Brazil. Only the type data.

New records. IBSP 11129C (3 larvae), Morro Grande, Cotia, state of São Paulo, 26-IV-2012, Akodon montensis (\#MGR 38).

32. Kymocta faitkeni Brennan, 1968: 614; Serra do Navio, Amapá state, Brazil, ex Hylaeamys megacephalus (= Oryzomys capito); USNM (holotype and paratypes, $\mathrm{n}^{\circ}$ 48875) and NHMUK (paratypes).

Records from Brazil. In addition to the type data, this species was record in the same locality and host by Brennan and van Bronswijk (1973) and was also found in Bragança (Pará) parasitizing Necromys lasiurus (= Zygodontomys lasiurus) (Rodentia) and Didelphis marsupialis (Didelphimorphia) (Brennan and van Bronswijk 1973).

Other records. Trinidad (Brennan 1968b) and Venezuela (Brennan and Yunker 1969, Brennan and van Bronswijk 1973).

33. Kymocta inca (Brennan \& Jones, 1961): 177; Quince Mil, Cuzco, Peru, Nephelomys keaysi (= Oryzomys keaysi); USNM (holotype and paratypes, $\mathrm{n}^{\circ} 33554$ ).

Records from Brazil. In addition to the type data, this species was record in the same locality and host by Brennan and van Bronswijk (1973) and on the rodent $P$. guyannensis in Bragança (Pará) (Brennan and van Bronswijk 1973).

Other records. Peru (Brennan and Jones 1961a) and Venezuela (Brennan and Yunker 1969).

34. Kymocta lutui Goff, Whitaker \& Dietz, 1983: 185; National Park of Serra da Canastra, Minas Gerais state, Brazil, Necromys lasiurus (= Zygodontomys lasiurus); BPBM (holotype and paratypes, $n^{\circ} 12712$ ).

Records from Brazil. Only the type data.

Genus Microtrombicula Ewing, 1950: 297

35. Microtrombicula brachytrichia Brennan, 1971: 214; Belém, Para state, Brazil, Proechimys guyannensis; USNM (holotype and paratypes $\mathrm{n}^{\circ}$ 50350).

Records from Brazil. Only the type data.

36. Microtrombicula brennani Goff, Whitaker \& Dietz, 1986: 171; Poço das Antas Biological Reserve, Rio de Janeiro state, Brazil, ex Lentopithecus rosalia; USNM (holotype and paratypes) and BPBM (paratypes).

Records from Brazil. Only the type data. 
37. Microtrombicula rhipidomysi Goff, Whitaker \& Dietz, 1983: 183; National Park of Serra da Canastra, state of Minas Gerais, Brazil, ex Rhipidomys mastacalis; BPBM (holotype, $\mathrm{n}^{\circ} 12710$ and paratypes)

Records from Brazil. Only the type data.

Genus Neoschoengastia Ewing, 1929: 187

38. Neoschoengastia esorhina Brennan, 1971: 666; Ananindeua, Pará state, Brazil, ex Automolus infuscatus, USNM (holotype and paratypes, ${ }^{\circ}$ 56193).

Records from Brazil. Only the type data.

Genus Parascoshoengastia Vercammen-Grandjean, 1960: 469

39. Parascoschoengastia aemulata (Brennan \& Jones, 1964): 307; Rancho Grande, Aragua, Venezuela, ex Anoura caudata; USNM (holotype and paratypes, $\mathrm{n}^{\circ} 40658$ ), FMNH (paratypes), OSAL (paratypes), BPNM (paratypes).

Records from Brazil. Present study.

New record. IBSP 12558 (1 larva), Morro Grande, Cotia, São Paulo, 20-X-2015, Akodon sp. (\#MGR 246).

Other records. Venezuela (Brennan and Jones 1964a).

Genus Parasecia Loomis, 1966: 191

40. Parasecia aitkeni (Brennan \& Jones, 1960): 510; Cumaca, Trinidad, ex Nectomys squamipes; USNM (holotype and paratypes, $\mathrm{n}^{\circ} 33628$ ), FHMUK (paratypes), FMNH (paratypes) and SAM (paratypes).

Records from Brazil. In addition to the type data, this species was found in the same locality, but parasitizing the marsupial Monodelphis domestica (Whitaker and Dietz 1987).

Other records. Bolivia (Brennan 1970a); Surinam (Brennan and Lukoschus 1971); Trinidad (Brennan and Jones 1960, Brennan 1969c) and Venezuela (Brennan and Reed 1975).

41. Parasecia fundata Brennan, 1969: 664; Belém, Pará state, and Serra do Navio, Amapá state, Brazil, ex Caluromys philander, Didelphis marsupialis and Glyphorynchus spirurus; USNM (holotype and paratypes, $\mathrm{n}^{\circ}$ 49323) and NHMUK (paratypes).

Records from Brazil. In addition to the type data, this species was also found parasitizing P. guyannensis in Serra do Navio (Amapá) (Brennan 1969c).

Other records. Costa Rica (Stekolnikov et al. 2007). 
42. Parasecia lasiurus Goff \& Gettinger, 1991: 401; Brasília, Federal District, Brazil, ex Necromys lasiurus and Oxymycterus sp.; MZSP (holotype), BPBM (paratypes), $\mathrm{OMNH}$ (paratypes).

Records from Brazil. Only the type data.

43. Parasecia orphana Brennan, 1971: 212; Belém, Pará state, Brazil, ex Proechimys guyannensis; USNM (holotype and paratypes, $\mathrm{n}^{\circ}$ 50351), NHMUK (paratypes), FMNH (paratypes).

Records from Brazil. Only the type data.

44. Parasecia thalurania Brennan, 1969: 663; Belém, Pará state, Brazil; ex Thalurania furcata; USNM (holotype, $\mathrm{n}^{\circ}$ 49374).

Records from Brazil. Only the type data.

45. Parasecia valida Brennan, 1969: 663; Bragança, Pará state, and Serra do Navio, Amapá state, Brazil, ex Hylaeamys megacephalus, Necromys lasiurus (= Zygodontomys lasiurus fuscinus) and Monodelphis brevicaudata; USNM (holotype and paratypes, $\mathrm{n}^{\circ}$ 49092) and NHMUK (paratypes).

Records from Brazil. Only the type data.

Other records. Surinam (Brennan and Lukoschus 1971).

Genus Paratrombicula Goff \& Whitaker, 1984: 329

46. Paratrombicula plaumanni (Brennan \& Jones, 1964): 309; Nova Teutônia, Santa Catarina state, Brazil, ex Ctenomys minutus; USNM (holotype and paratypes, $\mathrm{n}^{\circ} 34911$ ), NHMUK (paratypes), FMNH (paratypes), OSAL (paratypes), BPNM (paratypes).

Records from Brazil. Only the type data.

Other records. Chile (Stekolnikov and González-Acuña 2012).

Genus Perissopalla Brennan \& White, 1960: 303

47. Perissopalla barticonycteris Brennan, 1969: 429; Belém, Pará state, Brazil, ex Glyphonycteris daviesi; USNM (holotype and paratypes, $\mathrm{n}^{\circ}$ 49939).

Records from Brazil. Only the type data.

Other records. Bolivia (Brennan 1970a) and Surinam (Brennan and Lukoschus 1971, Brennan and van Bronswijk 1975).

48. Perissopalla ipeani Brennan, 1969: 429; Belém, Pará state, Brazil, ex Carollia perspicillata; USNM (holotype and paratypes, $\mathrm{n}^{\circ}$ 49366).

Records from Brazil. In addition to the type data, this species was also reported from Tonatia bidens (Chiroptera) in Parque Estadual Pedra Branca (Rio de Janeiro) (Almeida et al. 2011). 
Other records. Surinam (Brennan and van Bronswijk 1975, Brennan and Lukoschus 1971).

49. Perissopalla tanycera Brennan, 1969: 430; Icabarú, Bolivar, Venezuela, ex Peropteryx sp.; RML (holotype and paratypes, $\mathrm{n}^{\circ}$ 49833).

Records from Brazil. This species was found in Príncipe de Beira (Rondônia) parasitizing the bat Saccopteryx bilineata (Brennan 1970a).

Other records. Bolivia (Brennan 1970a); Surinam (Brennan and van Bronswijk 1975) and Venezuela (Brennan 1969b, Brennan and Reed 1975).

\section{Genus Polylopadium Brennan \& Jones, 1961: 112}

50. Polylopadium aspasium Brennan, 1969: 868; Serra do Navio, Amapá state and Bragança, Pará state, Brazil; ex H. megacephalus (= Oryzomys capito); RML (holotype and paratypes, $\left.n^{\circ} 49341\right)$.

Records from Brazil. In addition to the type data, this species was found in the same host, but in Belém (Pará) (Brennan 1969a).and also was found on the rodent Proechimys sp.in Príncipe da Beira (Rondônia) (Brennan 1970a).

Other records. Venezuela (Brennan and Reed 1975).

\section{Genus Quadraseta Brennan, 1970: 1695}

51. Quadraseta brasiliensis Goff \& Gettinger, 1989: 557; Brasília, Federal District, Brazil, ex Hylaeamys megacephalus, Gracilinannus agilis, Monodelphis Americana; MZSP (holotype), BPBM (paratypes) and OMNH (paratypes).

Records from Brazil. Only the type data.

52. Quadraseta flochi (Brennan \& Jones, 1960): 503; Maingot state, Trinidad, ex Rattus rattus; USNM (holotype and paratypes, $\left.\mathrm{n}^{\circ} 33885\right), \mathrm{FMNH}$ (paratypes), NHMUK (paratypes) and SAM (paratypes).

Records from Brazil. Present study.

New record. IBSP 11096F (2 larvae), Morro Grande, Cotia, São Paulo state, 20VI-2012, Euryoryzomys russatus (\#MGR 32).

Other records. Colombia (Brennan 1968a), Surinam (Brennan and Lukoschus 1971), Trinidad (Brennan and Jones 1960) and Venezuela (Brennan and Reed 1975).

53. Quadraseta mirandae Goff \& Brennan, 1977: 504; Quebrada Chacaito, Miranda, Venezuela, ex Nephelomys albigularis (= Oryzomys albigularis); USNM (holotype and paratypes, $\mathrm{n}^{\circ}$ 52518) and BPBM (paratypes).

Records from Brazil. Present study. 
New records. IBSP 10606C (1 larva), Morro Grande, Cotia, São Paulo state, 13IX-2011, Akodon montensis (\#MGR 6); 1 larva (IBSP 11129B), same locality and host (\#MGR 38), 26-VI-2012.

Other records. Venezuela (Goff and Brennan 1977).

54. Quadraseta pazca (Brennan \& Jones, 1964): 700; Azul, Buenos Aires, Argentina, ex Rattus sp. and Mus sp.; USNM (holotype and paratypes, ${ }^{\circ}$ 38090), NHMUK (paratypes), FMNH (paratypes) and OSAL (paratypes).

Records from Brazil. Whitaker and Dietz (1987) reported this species from the Serra da Canastra National Park (Minas Gerais) on the rodent Calomys tener.

New records. IBSP 10606B (1 larva), Morro Grande, Cotia, São Paulo state, 13IX-2011, Akodon montensis (\#MGR 6); 2 larvae (IBSP 11096E), same locality, 20-VI2012, Euryoryzomys russatus (\#MGR 32).

Other records. Argentina (Brennan and Jones 1964b).

55. Quadraseta trapezoides (Brennan \& Jones, 1964): 699; Azul, Buenos Aires, Argentina, ex "fox"; USNM (holotype and paratypes, n³8095), NHMUK (paratypes), FMNH (paratypes) and OSAL (paratypes).

Records from Brazil. Present study.

New record. IBSP $11110 \mathrm{C}$ (12 larvae), Morro Grande, Cotia, São Paulo state, 16VII-2012, Nectomys squamipes (\#MGR 40).

Other records. Argentina (Brennan and Jones 1964b).

Genus Rhinibius Brennan \& Yunker, 1969: 304

56. Rhinibus tamandua Brennan \& Yunker, 1969: 304; Belém, Pará state, ex Tamandua tetradactyla; USNM (holotype and paratypes, $n^{\circ}$ 49365), FMNH (paratypes) and NHMUK (paratypes).

Records from Brazil. Only the type data.

Other records. Venezuela (Brennan and Reed 1975, Brennan and Yunker 1969).

\section{Genus Serratacarus Goff \& Whitaker, 1984: 162}

57. Serratacarus dietzi Goff \& Whitaker, 1984: 163; Serra da Canastra National Park, Minas Gerais state, Brazil; ex Necromys lasiurus; USNM (holotype and paratypes) and BPBM (paratypes).

Records from Brazil. Only the type data.

58. Serratacarus lasiurus Goff \& Whitaker, 1984: 166; Serra da Canastra National Park, Minas Gerais state, Brazil; ex Necromys lasiurus; USNM (holotype and paratypes) and BPBM (paratypes).

Records from Brazil. Only the type data. 


\section{Genus Speleocola Lipovsky, 1952: 132}

59. Speleocola tamarina Goff, Whitaker \& Dietz, 1987: 198; Poço das Antas Biological Reserve, Rio de Janeiro state, Brazil, ex Lentopithecus rosalia; USNM (holotype and paratypes).

Records from Brazil. The type data and the present study.

New records. IBSP 11364B (1 larva), Morro Grande, Cotia, São Paulo, 21-VII2013, Sooretamys angouya (\#MGR 148).

\section{Genus Trombewingia Fonseca, 1955: 3}

60. Trombewingia bakeri (Fonseca, 1955): 3; Reserva Florestal do Horto Florestal de São Paulo, São Paulo state, Brazil, ex Guerlinguetus ingrami; IBSP (Lectotype and Paralectotypes, $n^{\circ}$ 344).

Records from Brazil. In addition to the type data, Whitaker and Dietz (1987) reported it from the Serra da Canastra National Park (Minas Gerais) parasitizing the marsupial $M$. domestica. Other recent reports from Sáo Paulo state include the municipality of Campos do Jordáo and municipality of Cotia parasitizing A. montensis, and the rodents Delomys dorsalis and Sooretamys angouya (Jacinavicius et al. 2015).

61. Trombewingia brasiliensis Goff \& Gettinger, 1991: 401; Brasília, Federal District, Brazil, ex Necromys lasiurus (= Bolomys lasiurus); MZSP (holotype), BPBM (paratypes) and OMNH (paratypes).

Records from Brazil. Only the type data.

\section{Genus Trombicula Berlese, 1905: 155}

62. Trombicula truncata Brennan, 1970: 272; Príncipe de Beira, Rondônia state, Brazil, ex Saccopteryx bilineata; USNM (holotype and paratypes, $\mathrm{n}^{\circ}$ 50188), FMNH (paratypes) and NHMUK (paratypes).

Records from Brazil. Only the type data.

Genus Vercammenia Audy \& Nadchatram, 1957: 95

63. Vercammenia yorkei (Sambon, 1928): 119; Urucum, Mato Grosso do Sul state, Brazil, ex Scinax funereus (= Hyla rubra); NHMUK (holotype, $\mathrm{n}^{\circ}$ 147-9).

Records from Brazil. Only the type data. 


\section{Acknowledgments}

To Debra D. Creel, SEL-USDA, Floyd Shockley and David Furth, NMNH for technical assistance with the chigger specimens and literature. To the Smithsonian NMNH, the Systematic Entomology Laboratory (USDA-ARS) for their support and material used in this study. This work was supported by the Conselho Nacional de Desenvolvimento Científico e Tecnológico (CNPq no. 454907/2014-1 to DMB-B and 377976/2014-8 to FCJ) and Fundação de Amparo à Pesquisa do Estado de São Paulo (FAPESP no. 2010/51875-9 to DMB-B and 2017/01416-7 to RB-S). Mention of trade names or commercial products in this publication is solely for the purpose of providing specific information and does not imply recommendation or endorsement by the USDA; USDA is an equal opportunity provider and employer.

\section{References}

Almeida JC, Silva SSP, Serra-Freire NM, Valim MP (2011) Ectoparasites (Insecta and Acari) associated with bats in Southeastern Brazil. Journal of Medical Entomology 48: 753-757. https://doi.org/10.1603/ME09133

Arnold KA (1970) Notes on Avian Ectoparasites from Costa Rica. I. Acarina and Diptera. Revista de Biologia Tropical 16: 259-265.

Audy JR, Nadchatram M (1957) Vercammenia, new genus of chiggers hypodermal in Amphibia (Acarina, Trombiculidae). Studies from the Institute for Medical Research Kuala Lumpur 28: $95-102$.

Azad AF, Beard CB (1998) Rickettsial pathogens and their arthropod vectors. Emerging Infectious Diseases 4: 179-186. https://doi.org/10.3201/eid0402.980205

Bassini-Silva R, Jacinavicius FC, Mendoza-Roldan JA, Daemon E, Barros-Battesti DM (2016) Description of Blankaartia shatrovi n. sp. (Acari: Trombiculidae) From Brazil. Journal of Medical Entomology 54: 82-90. https://doi.org/10.1093/jme/tjw149

Bennett SG, Loomis RB (1980) The tropical pest chigger, Eutrombicula batatas (Acarina: Trombiculidae), in Arizona and California, USA. Journal of Medical Entomology 17: 286-286. https://doi.org/10.1093/jmedent/17.3.286

Berlese A (1905) Acari nuovi. Manipulus IV. (Acari di Giava). Redia 2: 154-176.

Boshell J, Kerr JA (1942) Veinticinco especies nuevas de trombidiideos de Colombia. Revista de la Academia Colombiana de Ciencias Exactes 5: 110-127.

Brennan JM (1953) A note on the chiggers of Jamaica (Acarina: Trombiculidae). Journal of Parasitology 39: 292-295. https://doi.org/10.2307/3273952

Brennan JM (1965) Five New Chiggers from Southwestern United States (Acarina: Trombiculidae). The Journal of Parasitology 51: 108-113. https://doi.org/10.2307/3275656

Brennan JM (1967) New records of chiggers from the West Indies. Studies on the fauna of Curaçao and other Caribbean Islands XXIV: 146-156.

Brennan JM (1968a) A collection of chiggers (Acarina: Trombiculidae) from rodents in southwestern Colombia. The Journal of Parasitology 54: 679-685. https://doi.org/10.2307/3277019 
Brennan JM (1968b) Endoparasitic chiggers: IV. Revision of Kymocta Yunker and Brennan, 1962 (Acarina: Trombiculidae), with description of a new species. The Journal of Parasitology 54: 613-615. https://doi.org/10.2307/3277095

Brennan JM (1969a) Five new species of the unique genus Polylopadium (Acarina: Trombiculidae).

The Journal of Parasitology 55: 866-871. https://doi.org/10.2307/3277233

Brennan JM (1969b) New bat chiggers of the genus Perissopalla from Venezuela and Northeastern

Brazil (Acarina: Trombiculidae). Journal of Medical Entomology 6: 427-431. https://doi. org/10.1093/jmedent/6.4.427

Brennan JM (1969c) Three new species of subgenus Parasecia Loomis (genus Fonsecia) from Northeastern Brazil and a key to the included species (Acarina: Trombiculidae). The Journal of Parasitology 55: 662-666. https://doi.org/10.2307/3277312

Brennan JM (1970a) Chiggers from the Bolivian-Brazilian border (Acarina: Trombiculidae).

The Journal of Parasitology 56: 807-812. https://doi.org/10.2307/3277728

Brennan JM (1970b) Colicus, a new neotropical genus with descriptions of two new species and a key to included species (Acarina: Trombiculidae). Journal of Medical Entomology 7: 271-273. https://doi.org/10.1093/jmedent/7.2.271

Brennan JM (1970c) A small collection of chiggers from Surinam (Acarina: Trombiculidae). Bulletin of the Southern California Academy of Sciences 69: 32-37.

Brennan JM (1970d) Two new genera and a new species of Neotropical chiggers (Acarina: Trombiculidae). Annals of the Entomological Society of America 63: 1694-1696. https:// doi.org/10.1093/aesa/63.6.1694

Brennan JM (1971a) Endoparasitic chiggers. VI. Neoschoengastia esorhina sp. n. (Acarina: Trombiculidae), a second intranasal chigger of birds. The Journal of Parasitoogy 57: 666-667. https://doi.org/10.2307/3277936

Brennan JM (1971b) Three new chiggers from spiny rat, Proechimys guyannensis, in Northern Brazil (Acarina: Trombiculidae). Annals of the Entomological Society of America 64: 212-215. https://doi.org/10.1093/aesa/64.1.212

Brennan JM (1972) Buclypeus, new genus for Trombicula ignota Brennan, T. rotundiscutata Fauran, and two new species (Acarina: Trombiculidae). The Journal of Parasitology 58: 1178-1181. https://doi.org/10.2307/3278161

Brennan JM, van Bronswijk JEMH (1973) Endoparasitic Chiggers: VII. A redescription of Kymocta Yunker Brennan, 1962, a new species from Venezuela, and other records (Acarina: Trombiculidae). Journal of Medical Entomology 10: 449-451. https://doi.org/10.1093/ jmedent/10.5.449

Brennan JM, van Bronswijk JEMH (1975) Parasitic mites of Surinam XXI. New records of Surinam and certain French Guiana chiggers with the description of a new species of Loomisia Brennan \& Reed, 1972 (Acarina: Trombiculidae). Journal of Medical Entomology 12: 243-249. https://doi.org/10.1093/jmedent/12.2.243

Brennan JM, Dalmat HC (1960) Chiggers of Guatemala (Acarina: Trombiculidae). Annals of the Entomological Society of America 53: 183-191. https://doi.org/10.1093/aesa/53.2.183

Brennan JM, Goff ML (1977) Keys to the genera of chiggers of the western hemisphere (Acarina: Trombiculidae). The Journal of Parasitology 63: 554-566. https://doi. org/10.2307/3280021 
Brennan JM, Jones EK (1960) Chiggers of Trinidad, BWI (Acarina: Trombiculidae). Acarologia 2: 493-540.

Brennan JM, Jones EK (1961a) Chiggers of Peru (Acarina: Trombiculidae). Acarologia 3: 172-205. Brennan JM, Jones EK (1961b) New genera and species of chiggers from Panama (Acarina: Trombiculidae). The Journal of Parasitology 47: 105-124. https://doi.org/10.2307/3274993

Brennan JM, Jones EK (1964a) Five new species of chiggers from South America (Acarina: Trombiculidae). Journal of Medical Entomology 1: 307-310. https://doi.org/10.1093/ jmedent/1.3.307

Brennan JM, Jones EK (1964b) Four new chiggers from Argentina (Acarina: Trombiculidae). The Journal of Parasitology 50: 698-702. https://doi.org/10.2307/3276133

Brennan JM, Lukoschus F (1971) Parasitic of Surinam. VIII. A new genus and species of chigger, Fauranius atecmartus, and additional records of species (Acarina: Trombiculidae). Bulletin of the Southern California Academy of Sciences 70: 42-45.

Brennan JM, Reed JT (1974) The genus Eutrombicula in Venezuela (Acarina: Trombiculidae). The Journal of Parasitology 60: 699-711. https://doi.org/10.2307/3278741

Brennan JM, Reed JT (1975) A list of Venezuela chiggers, particularly of small mammalian hosts (Acarina: Trombiculidae). Brigham Young University Science Bulletin 20: 45-75.

Brennan JM, White JS (1960) New records and descriptions of chiggers (Acarina: Trombiculidae) on bats in Alabama. The Journal of Parasitology 46: 346-350. https://doi. org/10.2307/3275497

Brennan JM, Yunker CE (1966) The chiggers of Panama (Acarina: Trombiculidae). Panama, pp 221-266.

Brennan JM, Yunker CE (1969) Endoparasitic Chiggers: V. New genera, species and records from Venezuela and Brazil (Acarina: Trombiculidae). Journal of Medical Entomology 6: 299-304. https://doi.org/10.1093/jmedent/6.3.299

Carneiro LS (1949) Parasitose humana provocada por Apolonia tigipioensis Torres e Braga 1938 (Trombidiidae). Boletim da SAIC 16: 1-8.

Carneiro LS (1952) Uma nova acaríase humana. Continuição ao seu estudo. PhD thesis, Recife, Brazil: Universidade Federal do Pernambuco.

Carvalho ALG, Araujo AFB, Silva HR (2006) Patterns of parasitism by Eutrombicula alfreddugesi (Oudemans) (Acari, Trombiculidae) in three species of Tropidurus Wied (Squamata, Tropiduridae) from Cerrado habitat of Central Brazil. Revista Brasileira de Zoologia 23: 1010-1015. https://doi.org/10.1590/S0101-81752006000400005

Confalonieri UE, De Carvalho LP (1973) Occurrence of Trombicula (Eutrombicula) batatas (L.) in Gallus gallus domesticus L. in the State of Rio de Janeiro (Acarina, Trombiculidae). Revista Brasileira de Biologia 33: 7-10.

Confalonieri UEC, Benez EJ (1976) Note on a new host for Eutrombicula (Eutrombicula) batatas L. in Brazil (Acari: Trombiculidae). Revista Brasileira de Biologia 36: 353-355.

Contel FB (2014) As divisôes regionais do IBGE no século XX (1942, 1970 e 1990). Terra Brasilis (Nova Série)3: 1-21. https://doi.org/10.4000/terrabrasilis.990

Crossley DA Jr. (1960) Comparative external morphology and taxonomy of nymphs of the Trombiculidae (Acarina). The University of Kansas Science Bulletin 15: 135-321. 
Daniel M, Stekolnikov AA (2003) Chigger mites (Acari: Trombiculidae) new to the fauna of Cuba, with the description of two new species. Folia Parasitologica 50: 143-150. https:// doi.org/10.14411/fp.2003.025

Daniel M, Stekolnikov AA (2004) Chigger mites of the genus Eutrombicula Ewing, 1938 (Acari: Trombiculidae) from Cuba, with the description of three new species. Folia Parasitologica 51: 359-366. https://doi.org/10.14411/fp.2004.045

Delfino MM, Ribeiro SC, Furtado IP, Anjos LA, Almeida WO (2011) Pterygosomatidae and Trombiculidae mites infesting Tropidurus hispidus (Spix, 1825) (Tropiduridae) lizards in northeastern Brazil. Brazilian Journal of Biology 71: 549-555. https://doi.org/10.1590/ S1519-69842011000300028

Estébanes-González ML, Cervantes FA (2005) Mites and ticks associated with some small mammals in Mexico. International Journal of Acarology 31: 23-37. https://doi. org/10.1080/01647950508684413

Ewing HE (1925) A new chigger (Trombicula larva) from Brazil. Proceedings of the Entomological Society of Washington 27: 91-92.

Ewing HE (1929) A Manual of external parasites. Springfield, Illinois, 225 pp.

Ewing HE (1931) A catalogue of the Trombiculinae, or chigger mites, of the New World, with new genera and species and a key to the genera. Proceedings of the United States National Museum 80: 1-23. https://doi.org/10.5479/si.00963801.80-2908.1

Ewing HE (1938) A key to the genera of chiggers with descriptions of new genera and species. Journal of the Washington Academy of Sciences 28: 288-295.

Ewing HE (1944) Notes on the taxonomy of the Trombiculid Mites. Proceedings of the Biological Society of Washington 57: 101-104.

Ewing HE (1946) Notes on trombiculid mites with descriptions of Walchiinae n. subf., Speotrombicula n. g., and Eutrombicula defecta n. sp. The Journal of Parasitology 32: 435-440. https://doi.org/10.2307/3272913

Ewing HE (1950) A redescription of four genera of chigger mites, together with a redescription of a new genus and subgenus. Proceedings of the Entomological Society of Washington 52: 291-299.

Faccini JLH, Santos ACG, Santos SB, Jacinavicius FC, Bassini-Silva R, Barros-Battesti DM (2017) Trombiculiasis in domestic goats and humans in the state of Maranhão, Brazil. Revista Brasileira de Parasitologia Veterinária 26: 104-109. https://doi.org/10.1590/s198429612016088

Floch H, Fauran P (1956) Sur deux espèces du genre "Trombicula" (Acariens, Trombiculidés) nouvelles pour la faune de la Guyane Française: "Trombicula alfreddugesi” (Oudemans, 1910) et "Trombicula sinnamaryi" n. sp. Archives de l'Institut Pasteur de La Guyane Française et de l'Inini 17: 1-7.

Fonseca F (1932a) Notas de Acareologia V. Trombicula butantanensis sp. n. (Acarina, Trombidiidae). Memórias do Instituto Butantan 7: 148-150.

Fonseca F (1932b) Notas de Acareologia VI. Duas novas espécies de larvas do gênero Trombicula: Trombicula ophidica sp. n. e Trombicula ewingi, sp. n. (Acarina, Trombidiidae); nota sobre Trombicula butantanensis Fonseca, 1932 e sobre a inexistência de T. akamushi (Brumpt, 1910) entre nós. Memórias do Instituto Butantan 7: 151-158. 
Fonseca F (1936) Notas de Acareologia XXIII: novas especies de trombiculinae dos generos Trombicula, Hannemania e Neoschöngastia. Memórias do Instituto Butantan 10: 29-32.

Fonseca F (1955) Acarological notes XXXVII. Schoengastia (Trombewingia) bakeri, subg. n., sp. n., and notes on the parasitism of man by chigger mites from Brazil (Acari: Trombiculidae). Revista Brasileira de Entomologia 3: 1-12.

Gazêta GS, Amorim M, Bossi DEP, Linhares AX, Serra-Freire NM (2006) Caamembecaia gratiosus n. gen., n. sp. (Acari: Trombiculidae), from Trinomys gratiosus (Gunter) (Rodentia: Echimydae), of Atlantic forest in southeastern Brazil. Memórias do Instituto Oswaldo Cruz 101: 137-139. https://doi.org/10.1590/S0074-02762006000200003

Goff ML, Brennan JM (1977) A new monotypic genus of chiggers and four new species of Quadraseta from Venezuela (Acari: Trombiculidae). Western North American Naturalist 37: 501-509.

Goff ML, Gettinger D (1989) Two new species of Schoengastiine chiggers (Acari: Trombiculidae) from Brazil and rediagnosis of Arisocerus Brennan, 1970. Journal of Medical Entomology 26: 554-558. https://doi.org/10.1093/jmedent/26.6.554

Goff ML, Gettinger D (1991) Two new species of chiggers (Acari: Trombiculidae) from small mammals collected in Brazil. Journal of Medical Entomology 28: 401-404. https://doi. org/10.1093/jmedent/28.3.401

Goff ML, Whitaker JO (1984a) A new genus and two new species of schoengastiine chiggers (Acari: Trombiculidae) from a cane mouse in Brazil. International Journal of Entomology 26: $162-166$.

Goff ML, Whitaker JO, Dietz JM (1983) Three new species of chiggers (Acari: Trombiculidae) from Brazil. Journal of Medical Entomology 20: 183-188. https://doi.org/10.1093/jmedent/20.2.183

Goff ML, Whitaker JO, Dietz JM (1986) A new species of Microtrombicula (Acari: Trombiculidae) from the Golden Lion Tamarin in Brazil. International Journal of Acarology 12: 171-173. https://doi.org/10.1080/01647958608683460

Goff ML, Whitaker JO Jr. (1984b) A small collection of chiggers (Acari: Trombiculidae) from mammals collected in Paraguay. Journal of Medical Entomology 21: 327-335. https://doi. org/10.1093/jmedent/21.3.327

Goff ML, Whitaker JO Jr., Dietz JM (1987) The genus Speleocola (Acari: Trombiculidae) with description of a new species from Brazil and a key to the species. Journal of Medical Entomology 24: 198-200. https://doi.org/10.1093/jmedent/24.2.198

Hoffmann A (1949) Contribuciones al conocimiento de los trombiculidos mexicanos (1a parte). Revista de la Sociedad Mexicana de Historia Natural 10: 185-190.

Hoffmann A (1990) Los trombicúlidos de México (Acarida: Trombiculidae). Universidad Nacional Autónoma de México, México, 275 pp.

IUCN (2017) The IUCN Red List of threatened Species. Version 2017-2. http://www.iucnredlist.org. Downloaded on 14 September 2017.

Jacinavicius FC, Bassini-Silva R, Oliveira MVB, Hingst-Zaher E, Barros-Battesti DM (2015) Trombewingia bakeri (Fonseca, 1955) (Trombidiformes: Trombiculidae): Lectotype and paralectotype designation and new records. Systematic and Applied Acarology 20: 641-646. https://doi.org/10.11158/saa.20.6.6 
Jenkins DW (1949) Trombiculid mites affecting man. IV. Revision of Eutrombicula in the American Hemisphere. Annals of the Entomological Society of America 42: 289-318. https://doi.org/10.1093/aesa/42.3.289

Jones BM (1950) The penetration of the host tissue by the harvest mite, Trombicula autumnalis Shaw. Parasitology 40: 247-260. https://doi.org/10.1017/S0031182000018096

Kroman RA, Loomis RB, Swatek FE, Omieczynski DJ (1967) The presence of the yeastlike cells of probable symbiotic nature in trombiculid mites. In: Evans GO (Ed) Proceedings of the International Congress of Acarology, 2. Akad. Kiado, Budapest, 309-315.

Linnaeus C (1758) Systema naturae per regna tria naturae, secundum classes, ordines, genera, species, cum characteribus differentiis, synonymis, locis. Laurentii Salvii, Holmiae, 824 pp.

Lipovsky LJ (1952) A new genus and species of chigger mite (Acarina, Trombiculidae). Journal of the Kansas Entomological Society 25: 132-137.

Loomis RB (1966) A new genus, Fonsecula, and a new subgenus (Parasecia) of the genus Fonsecia (Acarina, Trombiculidae). Bulletin of the Southern California Academy of Sciences 65: 190- 191.

Loomis RB (1969) Chiggers (Acarina, Trombiculidae ) from vertebrates of the Yucatan Peninsula. Mexico. Miscellaneous Publication - University of Kansas, Museum of Natural History 50: $1-22$.

Loomis RB, Spath LC (1969) A new species of Odontacarus Ewing (Acarina: Trombiculidae) from lizards of Baja California sur, Mexico. Bulletin of the Southern California Academy of Sciences 68: 187-190.

Loomis RB, Stephens RC (1962) Marmosa canescens in Sonora, Mexico. Journal of Mammalogy 43: 111. https://doi.org/10.2307/1376895

Menezes VA, Fontes AF, Gettinger D, Sluys MV, Rocha CFD (2011) A morphometric study of Eutrombicula alfreddugesi (Acari: Trombiculidae) infesting four sympatric species of Tropidurus (Squamata: Tropiduridae) in northeastern Brazil. Phyllomedusa 10: 79-84. https:// doi.org/10.11606/issn.2316-9079.v10i1p79-84

Ornelas-Almeida MA, Oliveira FRB, Alessandra Estrela da Silva AE, Moreira ELT, Maia PCC, Duarte LFC, Murphy G, Ayres MCC (2007) Nodular trombiculinosis caused by Apolonia tigipioensis, Torres and Braga (1938), in an ostrich (Struthio camelus) and a house sparrow (Passer domesticus). Veterinary Parasitology 150: 374-377. https://doi.org/10.1016/j. vetpar.2007.09.020

Oudemans AC (1910) Acarologische aanteekeningen XXXIII. Entomologische Berichten (Amsterdam) 3: 83-90.

Oudemans AC (1911a) Acarologische aanteekeningen XXXV. Entomologische Berichten (Amsterdam) 3: 118-126. https://doi.org/10.5962/bhl.part.1135

Oudemans AC (1911b) Acarologische aanteekeningen XXXVI. Entomologische Berichten (Amsterdam) 3: 137-139. https://doi.org/10.5962/bhl.part.1136

Oudemans AC (1912) Die bis jetzt bekannten larven von Trombidiidae and Erythraeidae mit besonderer berkucksichtigung der fur den menschen schadlichen Arten. Zoologische Jahrbucher: Supplplement 1: 1-230.

Pearse AS, Creaser EP, Hall FG (1936) The cenotes of Yucatan. Carnegie Institution of Washington Publications, 304 pp. 
Poinar G Jr., Poinar R (1998) Parasites and pathogens of mites. Annual Review of Entomology 43: 449-469. https://doi.org/10.1146/annurev.ento.43.1.449

Radford CD (1942) The larval Trombiculinae (Acarina, Trombidiidae) with descriptions of twelve new species. Parasitology 34: 55-81. https://doi.org/10.1017/S0031182000015997 Reed JT, Brennan JM (1975) The subfamily Leeuwenhoekinae in the neotropics (Acarina: Trombiculidae). Brigham Young University Science Bulletin, Biological Series 20: 12-25.

Regolin AL, Furnari N, Jacinavicius FC, Linardi PM, Carvalho-Pinto CJ (2015) Ectoparasites of the critically endangered insular cavy, Cavia intermedia (Rodentia: Caviidae), southern Brazil. International Journal for Parasitology: Parasites and Wildlife 4: 37-42. https://doi. org/10.1016/j.ijppaw.2014.12.009

Rohani IB, Cromroy HL (1979) Taxonomy and distribution of chiggers (Acarina: Trombiculidae) in Northcentral Florida. The Florida Entomologist 62: 363-376. https://doi. org/10.2307/3493993

Sambon LW (1928) The parasitic acariens of animals and the part they play in the causation of the eruptive fevers and other diseases of man. Annals of Tropical Medicine and Parasitology 22: 67-132. https://doi.org/10.1080/00034983.1928.11684565

Silveira PSA, Bernardi LFO, Pepato AR (2015) New records of the genus Whartonia (Acari, Leeuwenhoekiidae) associated with the bat Carollia perspicillata from southeastern Brazil. Check List 11: 1793. https://doi.org/10.15560/11.6.1793

Spalding MG, Wrenn WJ, Schwikert ST, Schmidt JA (1997) Dermatitis in young Florida sandhill cranes (Grus canadensis pratensis) due to infestation by the chigger, Blankaartia sinnamaryi. The Journal of Parasitology 83: 768-771. https://doi.org/10.2307/3284263

Stekolnikov AA, González-Acuña D (2015) A review of Chilean chiggers (Acari: Trombiculidae), with the description of a new genus and ten new species. Zootaxa 3964: 1-43. https://doi.org/10.11646/zootaxa.3964.1.1

Stekolnikov AA, González-Acuña D (2012) A revision of the chigger mite genus Paratrombicula Goff \& Whitaker, 1984 (Acari: Trombiculidae), with the description of two new species. Systematic Parasitology 83: 105-115. https://doi.org/10.1007/s11230-012-9373-8

Stekolnikov AA, Literak I, Capek M, Havlck M (2007) Chigger mites (Acari: Trombiculidae) from wild birds in Costa Rica, with a description of three new species. Folia Parasitologica 54: 59-67. https://doi.org/10.14411/fp.2007.008

Torres S, Braga W (1938) Nova parasitose em pintos (nota prévia). Boletim da Sociedade Brasileira de Medicina Veterinária 3: 171-172.

Vercammen-Grandjean PH (1960) Introduction à un essai de classification rationelle des larves de Trombiculinae Ewing, 1944 (Acarina: Trombiculidae). Acarologia 2: 469-471.

Vercammen-Grandjean PH (1966) Whartonia pachywhartoni n. sp., an extraordinary parasite of a Brazilian, bat. (Leeuwenhoekiidae - Acarina). Acarologia 8: 282-284.

Vercammen-Grandjean PH (1967) Revision of the genus Tecomatlana Hoffmann, 1947 (Acarina: Trombiculidae). Acarologia 9: 848-864.

Webb JP Jr., Loomis RB (1977) Ectoparasites. In: Baker RJ, Jones Jr. JK, Carter DC (Eds) Biology of bats of the New World family Phyllostomatidae. Special publications of the Museum, Texas Tech University, Texas, 57-119. 
Wen T-H (1999) New taxa and tentative rearrangement of Walchiidae stat. n. with remarks on Trombiculoidea nec Welbourn, 1991 (Acari: Acariformes). Systematic and Applied Acarology 4: 165-178. https://doi.org/10.11158/saa.4.1.24

Wharton GW (1938) Acarina of Yucatan caves. Carnegie Institution of Washington Publications 491: 137-152.

Wharton GW, Fuller HS (1952) A manual of the chiggers: The biology, classification, distribution and importance to man of the larvae of the family Trombiculidae (Acarina). Memoirs of the Entomology Society of Washington, $185 \mathrm{pp}$.

Whitaker JO Jr., Dietz JM (1987) Ectoparasites and other associates of some mammals from Minas Gerais, Brazil. Entomological News 98: 189-197.

Womersley H (1944) Notes on and additions to the Trombiculinae and Leeuwenhoekiinae (Acarina) of Australia and New Guinea. Transactions of The Royal Society of South Australia 68: 82- 112.

Yunker CE, Brennan JM (1962) Endoparasitic chiggers: II. Rediscovery of Doloisia synoti Oudemans, 1910, with descriptions of a new subgenus and two new species (Acarina: Trombiculidae). Acarologia 4: 570-576.

\section{Appendix I}

Taxonomic list of chiggers and their respective hosts.

\section{Leeuwenhoekiidae}

\section{Apolonia tigipioensis Torres \& Braga, 1938}

Aves

Galliformes

Phasianidae

Gallus gallus domesticus

Passeriformes

Passeridae

Passer domesticus

Struthioniformes

Struthionidae

Struthio camelus

Tinamiformes

Tinamidae

Nothura maculosa cearensis

Mammalia

Primates

Hominidae

Homo sapiens 
Hannemania hepatica Fonseca, 1936

Amphibia

Anura

Leptodactylidae

Leptodactylus latrans

Hannemania hylodeus (Oudemans, 1910)

Amphibia

Anura

Hylodidae

Hylodes sp.

Hannemania newsteadi Sambon, 1928

Amphibia

Anura

Hylidae

Scinax funereus

Hannemania stephensi Sambon, 1928

Amphibia

Anura

Craugastoridae

Pristimantis conspicillatus

Leeuwenhoekia verduni (Oudemans, 1910)

Mammalia

Didelphimorphia

Didelphidae

Didelphis sp.

Whartonia nudosetosa (Wharton, 1938)

Mammalia

Chiroptera

Phyllostomidae

Carollia perspicillata

Whartonia pachywhartoni Vercammen-Grandjean, 1966

Mammalia

Chiroptera

Phyllostomidae

Carollia perspicillata

Micronycteris megalotis 


\section{Trombiculidae}

Aitkenius vellosus Brennan, 1970

Mammalia

Rodentia

Cricetidae

Hylaeamys megacephalus

Nectomys squamipes

Echimyidae

Proechimys guyannensis

\section{Arisocerus amapensis Brennan, 1970}

Mammalia

Rodentia

Cricetidae

Euryoryzomys macconnelli

Hylaeamys megacephalus

Echimyidae

Proechimys guyannensis

Arisocerus hertigi (Brennan \& Jones, 1964)

Mammalia

Didelphimorphia

Didelphidae

Didelphis albiventris

Rodentia

Caviidae

Cavia intermedia

Blankaartia shatrovi Bassini-Silva \& Barros-Battesti, 2016

Aves

"bird"

Passeriformes

Thraupidae

Trichothraupis melanops

\section{Blankaartia sinnamaryi Floch \& Fauran, 1956}

Aves

Passeriformes

Conopophagidae

Conopophaga lineata

Pipridae

Manacus manacus 
Thamnophilidae

Thamnophilus caerulescens

Thraupidae

Tachyphonus coronatus

Turdida

Turdus albicollis

Turdus rufiventris

Piciformes

Picidae

Picumnus cirratus

Mammalia

Primates

Hominidae

Homo sapiens

Buclypeus catatonus Brennan, 1972

Mammalia

Rodentia

Echimyidae

Proechimys guyannensis

Buclypeus ignotus (Brennan, 1971)

Mammalia

Rodentia

Echimyidae

Proechimys guyannensis

Caamembecaia gratiosus Gazêta, Amorim, Bossi, Linhares \& Serra-Freire, 2006 Mammalia

Rodentia

Echimyidae

Trinomys gratiosus

Chiroptella (Oudemansidium) australis (Brennan, 1970)

Mammalia

Chiroptera

Molossidae

Nyctinomops laticaudatus 
Colicus brasiliensis Goff, Whitaker \& Dietz, 1983

Mammalia

Rodentia

Cricetidae

Cerradomys subflavus

Oligoryzomys fornesi

Colicus icomi Brennan, 1970

Mammalia

Rodentia

Echimyidae

Proechimys guyannensis

\section{Colicus spinosus Goff \& Gettinger, 1989}

Mammalia

Didelphimorphia

Didelphidae

Gracilinannus agilis

Monodelphis sp.

Euschoengastia trouessarti (Oudemans, 1910)

Mammalia

Didelphimorphia

Didelphidae

Didelphis sp.

Eutrombicula alfreddugesi Oudemans, 1910

Mammalia

Artiodactyla

Bovidae

"goats"

Primates

Hominidae

Homo sapiens

Reptilia

Squamata

Colubridae

Xenodon merremii

Tropiduridae

Tropidurus cocorobensis

Tropidurus erythrocephalus

Tropidurus hispidus

Tropidurus itambere 


\section{Tropidurus oreadicus}

Tropidurus semitaeniatus

Tropidurus torquatus

Eutrombicula batatas (Linnaeus, 1758)

Aves

Galliformes

Phasianidae

Gallus domesticus

Meleagris gallopavo

Mammalia

Artiodactyla

Cervidae

Unidentified

Bovidae

Perissodactyla

"goats"

Equidae

"Equines"

Rodentia

Dasyproctidae

Dasyprocta agouti

Eutrombicula bruyanti (Oudemans, 1910)

Mammalia

Didelphimorphia

Didelphidae

Didelphis sp.

Eutrombicula goeldii (Oudemans, 1910)

Mammalia

Rodentia

Dasyproctidae

Dasyprocta agouti

Eutrombicula tinami (Oudemans, 1910)

Aves

Tinamiformes

Tinamidae

Crypturellus noctivagus

Mammalia

Didelphimorphia

Didelphidae

Didelphis aurita 
Fonsecia ewingi (Fonseca, 1932)

Reptilia

Squamata

Colubridae

Xenodon merremii

Fonsecia ophidica (Fonseca, 1932)

Reptilia

Squamata

Colubridae

Xenodon merremii

Fonsecia travassosi (Fonseca, 1936)

Reptilia

Squamata

Colubridae

Spilotes pullatus

Hooperella spinirostra (Vercammen-Grandjean, 1967)

Mammalia

Chiroptera

Phyllostomidae

Micronycteris megalotis

Kymocta brasiliensis (Fonseca, 1936)

Mammalia

Rodentia

"wild mouse"

Cricetidae

Akodon montensis

Kymocta faitkeni Brennan, 1968

Mammalia

Didelphimorphia

Didelphidae

Didelphis marsupialis

Rodentia

Cricetidae

Hylaeamys megacephalus

Necromys lasiurus 
Kymocta inca (Brennan \& Jones, 1961)

Mammalia

Rodentia

Cricetidae

Hylaeamys megacephalus

Echimyidae

Proechimys guyannensis

Kymocta lutui Goff, Whitaker \& Dietz, 1983

Mammalia

Rodentia

Cricetidae

Necromys lasiurus

Microtrombicula brachytrichia Brennan, 1971

Mammalia

Rodentia

Echimyidae

Proechimys guyannensis

Microtrombicula brennani Goff, Whitaker \& Dietz, 1986

Mammalia

Primates

Callitrichidae

Lentopithecus rosalia

Microtrombicula rhipidomysi Goff, Whitaker \& Dietz, 1983

Mammalia

Rodentia

Cricetidae

Rhipidomys mastacalis

Neoschoengastia esorbina Brennan, 1971

Aves

Passeriformes

Furnariidae

Automolus infuscatus

Parascoschoengastia aemulata (Brennan \& Jones, 1964)

Mammalia

Rodentia

Cricetidae

Akodon sp. 
Parasecia aitkeni (Brennan \& Jones, 1960)

Mammalia

Didelphimorphia

Didelphidae

Monodelphis domestica

Rodentia

Cricetidae

Calomys tener

Nectomys squamipes

Parasecia fundata Brennan, 1969

Aves

Passeriformes

Dendrocolaptidae

Glyphorynchus spirurus

Mammalia

Didelphimorphia

Didelphidae

Caluromys philander

Didelphis marsupialis

Rodentia

Echimyidae

Proechimys guyannensis

Parasecia lasiurus Goff \& Gettinger, 1991

Mammalia

Rodentia

Cricetidae

Necromys lasiurus

Oxymycterus sp.

Parasecia orphana Brennan, 1971

Mammalia

Rodentia

Echimyidae

Proechimys guyannensis

Parasecia thalurania Brennan, 1969

Aves

Apodiformes

Trochilidae

Thalurania furcata 
Parasecia valida Brennan, 1969

Mammalia

Didelphimorphia

Didelphidae

Monodelphis brevicaudata

Rodentia

Cricetidae

Hylaeamys megacephalus

Necromys lasiurus

Paratrombicula plaumanni (Brennan \& Jones, 1964)

Mammalia

Rodentia

Ctenomyidae

Ctenomys minutus

Perissopalla barticonycteris Brennan, 1969

Mammalia

Chiroptera

Phyllostomidae

Glyphonycteris daviesi

Perissopalla ipeani Brennan, 1969

Mammalia

Chiroptera

Phyllostomidae

Carollia perspicillata

Tonatia bidens

Perissopalla tanycera Brennan, 1969

Mammalia

Chiroptera

Emballonuridae

Saccopteryx bilineata

Polylopadium aspasium Brennan, 1969

Mammalia

Rodentia

Cricetidae

Hylaeamys megacephalus

Echimyidae

Proechimys sp. 
Quadraseta brasiliensis Goff \& Gettinger, 1989

Mammalia

Didelphimorphia

Didelphidae

Gracilinannus agilis

Monodelphis americana

Rodentia

Cricetidae

Hylaeamys megacephalus

Quadraseta flochi (Brennan \& Jones, 1960)

Mammalia

Rodentia

Cricetidae

Euryoryzomys russatus

Quadraseta mirandae Goff \& Brennan, 1977

Mammalia

Rodentia

Cricetidae

Akodon montensis

Quadraseta pazca (Brennan \& Jones, 1964)

Mammalia

Rodentia

Cricetidae

Euryoryzomys russatus

Calomys tener

Quadraseta trapezoides (Brennan \& Jones, 1964)

Mammalia

Rodentia

Cricetidae

Nectomys squamipes

Rhinibus tamandua Brennan \& Yunker, 1969

Mammalia

Pilosa

Myrmecophagidae

Tamandua tetradactyla 
Serratacarus dietzi Goff \& Whitaker, 1984

Mammalia

Rodentia

Cricetidae

Nectomys lasiurus

Serratacarus lasiurus Goff \& Whitaker, 1984

Mammalia

Rodentia

Cricetidae

Nectomys lasiurus

Speleocola tamarina Goff, Whitaker \& Dietz, 1987

Mammalia

Primates

Callitrichidae

Lentopithecus rosalia

Rodentia

Cricetidae

Sooretamys angouya

Trombewingia bakeri (Fonseca, 1955)

Mammalia

Rodentia

Cricetidae

Akodon montensis

Delomys dorsalis

Sooretamys angouya

Sciuridae

Guerlinguetus ingrami

Didelphimorphia

Didelphidae

Monodelphis domestica

Trombewingia brasiliensis Goff \& Gettinger, 1991

Mammalia

Rodentia

Cricetidae

Necromys lasiurus (= Bolomys lasiurus) 
Trombicula truncata Brennan, 1970

Mammalia

Chiroptera

Emballonuridae

Saccopteryx bilineata

Vercammenia yorkei (Sambon, 1928)

Amphibia

Anura

Hylidae

Scinax funereus

\section{Appendix 2}

List of hosts, their associations with chiggers and the respective reference.

Amphibia

Anura

Craugastoridae

Pristimantis conspicillatus

Hannemania stephensi Sambon 1928

Hylidae

Scinax funereus

Hannemania newsteadi Sambon 1928

Vercammenia yorkei Sambon 1928

Hylodidae

Hylodes sp.

Hannemania hylodeus Oudemans 1910

Leptodactylidae

Leptodactylus latrans

Hannemania hepatica Fonseca 1936

Reptilia

Squamata

Colubridae

Spilotes pullatus

Fonsecia travassosi Fonseca 1936

Xenodon merremii

Eutrombicula alfreddugesi Fonseca 1932a

Fonsecia ewingi Fonseca 1932b

Fonsecia ophidica Fonseca 1932b 
Tropiduridae

Tropidurus cocorobensis

Eutrombicula alfreddugesi Menezes et al. 2011

Tropidurus erythrocephalus

Eutrombicula alfreddugesi Menezes et al. 2011

Tropidurus hispidus

Eutrombicula alfreddugesi Delfino et al. 2011, Menezes et al. 2011

Tropidurus itambere

Eutrombicula alfreddugesi Carvalho et al. 2006

Tropidurus oreadicus

Eutrombicula alfreddugesi Carvalho et al. 2006

Tropidurus semitaeniatus

Eutrombicula alfreddugesi Menezes et al. 2011

Tropidurus torquatus

Eutrombicula alfreddugesi Carvalho et al. 2006

Aves

"bird"

Apodiformes

Blankaartia shatrovi Bassini-Silva et al. 2016

Trochilidae

Thalurania furcata

Parasecia thalurania Brennan 1969c

Galliformes

Phasianidae

Gallus domesticus

Apolonia tigipioensis Torres and Braga 1938

Eutrombicula batatas Ewing 1925, Confalonieri and De Carvalho 1973

Meleagris gallopavo

Eutrombicula batatas Ewing 1925

Passeriformes

Conopophagidae

Conopophaga lineata

Blankaartia sinnamaryi Bassini-Silva et al. 2016

Dendrocolaptidae

Glyphorynchus spirurus

Parasecia fundata Brennan 1969c

Furnariidae

Automolus infuscatus

Neoschoengastia esorbina Brennan 1971a 
Pipridae

Manacus manacus

Blankaartia sinnamaryi Bassini-Silva et al. 2016

Passeridae

Passer domesticus

Apolonia tigipioensis Ornelas-Almeida et al. 2007

Thamnophilidae

Thamnophilus caerulescens

Blankaartia sinnamaryi Bassini-Silva et al. 2016

Thraupidae

Tachyphonus coronatus

Blankaartia sinnamaryi Bassini-Silva et al. 2016

Trichothraupis melanops

Blankaartia shatrovi Bassini-Silva et al. 2016

Turdidae

Turdus albicollis

Blankaartia sinnamaryi Bassini-Silva et al. 2016

Turdus rufiventris

Blankaartia sinnamaryi Bassini-Silva et al. 2016

Piciformes

Picidae

Picumnus cirratus

Blankaartia sinnamaryi Bassini-Silva et al. 2016

Struthioniformes

Struthionidae

Struthio camelus

Apolonia tigipioensis Ornelas-Almeida et al. 2007

Tinamiformes

Tinamidae

Crypturellus noctivagus

Eutrombicula tinami Oudemans 1910

Nothura maculosa cearensis

Apolonia tigipioensis Carneiro 1949, 1952

Mammalia

Artiodactyla

Bovidae

Goats

Eutrombicula batatas Faccini et al. 2017

Eutrombicula alfreddugesi Faccini et al. 2017 
Cervidae

Unidentified

Eutrombicula batatas Bequaert 1926

Chiroptera

Emballonuridae

Saccopteryx bilineata

Perissopalla tanycera Brennan 1970a

Trombicula truncata Brennan 1970a

Phyllostomidae

Carollia perspicillata

Perissopalla ipeani Brennan 1969b

Whartonia nudosetosa Silveira et al. 2015

Whartonia pachywhartoni Silveira et al. 2015

Glyphonycteris daviesi

Perissopalla barticonycteris Brennan 1969b

Micronycteris megalotis

Hooperella spinirostra Vercammen-Grandjean 1967

Whartonia pachywhartoni Vercammen-Grandjean 1966

Tonatia bidens

Perissopalla ipeani Almeida et al. 2011

Molossidae

Nyctinomops laticaudatus

Chiroptella (Oudemansidium) australis Brennan 1970a

Didelphimorphia

Didelphidae

Caluromys philander

Parasecia fundata Brennan 1969c

Didelphis albiventris

Arisocerus hertigi Goff and Gettinger 1989

Didelphis aurita

Eutrombicula tinami this study

Didelphis marsupialis

Kymocta faitkeni Brennan and Bronswijk 1973

Parasecia fundata Brennan 1969c

Didelphis sp.

Euschoengastia trouessarti Oudemans 1910

Eutrombicula bruyanti Oudemans 1910

Leeuwenhoekia verduni Oudemans 1910

Gracilinannus agilis

Colicus spinosus Goff and Gettinger 1989

Quadraseta brasiliensis Goff and Gettinger 1989

Monodelphis americana

Quadraseta brasiliensis Goff and Gettinger 1989 
Monodelphis brevicaudata

Parasecia valida Brennan 1969c

Monodelphis domestica

Parasecia aitkeni Whitaker and Dietz 1987

Trombewingia bakeri Whitaker and Dietz 1987

Monodelphis sp.

Perissodactyla

Colicus spinosus this study

Equidae

"Equines" Confalonieri and Benez 1976

Eutrombicula batatas

Pilosa

Myrmecophagidae

Tamandua tetradactyla

Rhinibus tamandua Brennan and Yunker 1969

Primates

Callitrichidae

Lentopithecus rosalia

Microtrombicula brennani Goff et al. 1986

Speleocola tamarina Goff et al. 1987

Hominidae

Homo sapiens

Apolonia tigipioensis Carneiro 1949, 1952

Eutrombicula alfreddugesi Fonseca 1932a

Rodentia

Unknown

"wild mouse"

Kymocta brasiliensis Fonseca 1936

Caviidae

Cavia intermedia

Arisocerus hertigi Regolin et al. 2015

Cricetidae

Akodon montensis

Kymocta brasiliensis this study

Quadraseta mirandae this study

Quadraseta pazca this study

Trombewingia bakeri Jacinavicius et al. 2015

Akodon sp.

Parascoschoengastia aemulata this study

Calomys tener

Parasecia aitkeni Whitaker and Dietz 1987

Quadraseta pazca Whitaker and Dietz 1987 
Cerradomys subflavus

Colicus brasiliensis Goff et al. 1983

Delomys dorsalis

Trombewingia bakeri Jacinavicius et al. 2015

Euryoryzomys macconnelli

Arisocerus amapensis Brennan 1970

Euryoryzomys russatus

Quadraseta flochi this study

Quadraseta pazca this study

Necromys lasiurus

Kymocta faitkeni Brennan and Bronswijk 1973

Kymocta lutui Goff et al. 1983

Parasecia lasiurus Goff and Gettinger 1991

Parasecia valida Brennan 1969c

Serratacarus dietzi Goff and Whitaker 1984a

Serratacarus lasiurus Goff and Whitaker 1984a

Trombewingia brasiliensis Goff and Gettinger 1991

Nectomys squamipes

Aitkenius vellosus Brennan 1970d

Parasecia aitkeni Brennan and Jones 1960, Whitaker and Dietz 1987

Quadraseta trapezoides this study

Hylaeamys megacephalus

Aitkenius vellosus Brennan 1970d

Arisocerus amapensis Brennan 1970c

Kymocta faitkeni Brennan 1968b

Kymocta inca Brennan 1968b, Brennan and Bronswijk 1973

Parasecia valida Brennan 1969c

Polylopadium aspasium Brennan 1969a

Quadraseta brasiliensis Goff and Gettinger 1989

Oligoryzomys fornesi

Colicus brasiliensis Goff et al. 1983

Oxymycterus sp.

Parasecia lasiurus Goff and Gettinger 1991

Rhipidomys mastacalis

Microtrombicula rhipidomysi Goff et al. 1983

Sooretamys angouya

Speleocola tamarina this study

Trombewingia bakeri Jacinavicius et al. 2015

Ctenomyidae

Ctenomys minutus

Paratrombicula plaumanni Brennan and Jones 1964 a 
Dasyproctidae

Dasyprocta aguti

Eutrombicula batatas Bequaert 1926

Eutrombicula goeldii Oudemans 1910

Echimyidae

Proechimys guyannensis

Aitkenius vellosus Brennan 1970

Arisocerus amapensis Brennan 1970c

Buclypeus catatonus Brennan 1972

Buclypeus ignotus Brennan 1971b

Colicus icomi Brennan 1970b

Kymocta inca Brennan and Bronswijk 1973

Microtrombicula brachytrichia Brennan 1971b

Parasecia fundata Brennan 1969c

Parasecia orphana Brennan 1971b

Proechimys sp.

Polylopadium aspasium Brennan 1970a

Trinomys gratiosus

Sciuridae

Caamembecaia gratiosus Gazêta et al. 2006

Guerlinguetus ingrami

Trombewingia bakeri Fonseca 1955 